\title{
The Last Utopia: A Conversation about the History of Human Rights ${ }^{1}$
}

This chapter is a slightly revised transcript of the conversation between Hans Joas and Samuel Moyn at the University of Bielefeld on June 28, 2013. The public event was moderated by David Kim.

DK: We have invited Hans and Sam to engage with the audience in an interdisciplinary dialogue about the genealogy of human rights. This event is a valuable extension of our three-day-long conference because it exemplifies the best of interdisciplinary approaches to the history of human rights today. ${ }^{2}$ In The Sacredness of the Person, which has recently appeared in English translation with Georgetown University Press, Hans crisscrosses between sociology, religion, history, and philosophy. ${ }^{3}$ In The Last Utopia, Sam guides his readers through history, law, and political science. ${ }^{4}$ My own training is in cultural and literary studies, so I hope that this conversation will shake things up in exciting ways.

To warm us up for the discussion, I have asked Hans and Sam to begin by saying a few words about their books. The questions that I have shared with them in advance include the following: what were their points of entry into the history of human rights? How did their work evolve in the course of reading and writing? And what was the crux of their main argument? Afterward, I would like to raise a set of questions and ask others to join me as well. So without further ado, Sam, please begin.

SM: It is a great privilege to be here. I have heard the term "debate" used in the last few hours to refer to this event, but I want to make clear at the start that I am

1 The editors would like to thank Mark Phillips and Adam Orange, Ph.D. students in German Studies at Michigan State University, for their assistance with transcribing the recorded event.

2 Co-sponsored by the Center for Interdisciplinary Research (Zentrum für Interdisziplinäre Forschung) at Bielefeld University and the German Research Foundation (Deutsche Forschungsgemeinschaft), the conference involved scholars of human rights from the social sciences and the humanities and it took place at Bielefeld University on June 28-30, 2013.

3 Hans Joas, The Sacredness of the Person: A New Genealogy of Human Rights. Washington, DC: Georgetown University Press, 2013.

4 Samuel Moyn, The Last Utopia: Human Rights in History. Cambridge, MA: Belknap Press, 2010.

(c) BY-NC-ND (c) 2015 Hans Joas and Samuel Moyn, published by De Gruyter.

This work is licensed under the Creative Commons Attribution-NonCommercial-NoDerivs 3.0 License. 
not approaching it at all in that way. For one thing, I would lose. But the main reason is that I found Hans's book quite educational and stimulating. I have little in it with which I disagree, although perhaps a few points of distinction to draw out. I actually think that the books are about somewhat different topics, so what I thought I would do instead of giving you a genealogy of my book was to say a few words about some big differences between these two accounts of where human rights came from. I want to start by saying that Hans and I begin with a very similar fundamental premise, and that is: a historical understanding needs to incorporate an intellectual history of concepts and norms, but must go far further. Where we diverge is where we go, what we are trying to explain when we say we are trying to think historically about human rights, and then how we explain it. That said, I would maintain that our arguments are generally compatible.

My main premise in The Last Utopia is that we need a history that's oriented not simply to the normative substance of human rights, but also to two other major factors. The first one I'll call cultural salience and the second I'll call political scale. ${ }^{5}$

One of my main concerns in the book is to consider and even to measure how present or salient the idea of human rights was in philosophy or politics or the public sphere from time to time and from place to place. And I think it's at this point that a big difference between us enters. Generally, Hans thinks that once there's a politically important text on the table like the French Declaration of the Rights of Man and Citizen of 1789 or the Universal Declaration of Human Rights of 1948, there cannot be any doubt that human rights are already culturally central. Then he takes up the task of explaining this centrality: "How did this centrality come about?” By contrast, I doubt that a text is enough. I agree that we must move from norm to text, but human rights are about much more than just the text in which norms are announced and the political processes that lead to those text. I won't say much about the French Revolution unless we come back to it, but my main starting point in thinking about this topic is the following observation: the Universal Declaration of Human Rights seems to have been by and large ignored in its own time, whereas it's now central to our moral consciousness. For that reason, when it comes to historicizing this salience or centrality of human rights today, I don't think we can stop with the text of the Universal Declaration precisely because it seems to have stimulated little - whether philosophically or mobilizationally - in its time. This explains why our books are so different in their chronological coverage. Hans doesn't go beyond 1948, whereas I think almost

5 For more on these terms, see Samuel Moyn, "Substance, Scale, and Salience: The Recent Historiography of Human Rights.” Annual Review of Law and Social Science 8 (2012): 123-140. 
everything of interest happens after that date, although a lot might depend on how much is in the word "almost." In case you haven't read it, which I assume is almost universal here, my book emphasizes the later Cold War origins of the salience or prominence of human rights in culture.

My case is also furthered by my concern for thinking about political scale. The second fundamental premise in the book is that if we haven't described and explained international human rights politics as opposed to domestic citizenship politics, then in my view we haven't begun to think about what human rights mean to us now. And, among other things, I think this internationalization - or scalar leap of rights from domestic spaces to the globe - is one of the central distinguishing features of human rights, as we understand them now. And if we haven't historicized this scalar leap, then we will have omitted something quite significant.

Much of my book is about that problem. It involves a contrast between rights and domestic citizenship contexts, and rights in the form of international human rights politics. And it's in part for that reason that I emphasize the global South so heavily in my book. Again, this material is largely absent from Hans's book up until the presence of a few actors in 1948 who are involved in formulating the Universal Declaration. In my view, however, the Universal Declaration of Human Rights was still compatible with an imperial world and most of its framers understood it in that way. The major anticolonial and decolonizing movements of history after World War II seemed to be very different in their aspirations, their stated norms, and their mobilizational strategies than international human rights movements today. Understanding the intervening forms of anticolonialism as predecessors to contemporary human rights seems to me utterly central not least since human rights are primarily today a project directed towards the suffering in the formerly colonized world. If we haven't understood how they've become that postimperial project, then we won't have understood much about human rights.

Lastly, I'm very concerned - I think in contrast to Hans again since I'm not mentioning all the things we share - by economic context. Or to put it differently, I'm very interested in the relationship between what I'll call welfarism and rights. In my approach, the Universal Declaration of Human Rights in the 1940s is primarily offering one idiom for national welfarism, as I call it. In my understanding, this was the victorious ideology of World War II. It encapsulated ideologically how states should govern themselves and what sort of citizenship they should offer their citizens. And that's why, given the priority of welfarism, economic and social rights were so consensually central to human rights ideas in the 1940s.

But if that's true, I see something disturbing about our world. The era of international human rights politics - the age of that scalar leap I talked about - seems 
to be not a welfarist age anymore. Indeed, it seems to be one in which human rights are prominent, but we've headed, unlike after the 1940s, into a world that has some of the greatest inequalities both within and among nations that the globe has ever seen. I think the history of human rights should put this disturbing fact center stage. What, I wonder, is the relationship between the rise of international human rights and the collapse of domestic welfarism ideologically? These two developments have the same chronology and the question is whether they're related in deep ways and are not just companions across the same timeline.

So finally, for all those reasons, I don't see human rights history either as a triumphalist celebration - and Hans doesn't either, I know; nor do I develop anything like what he very interestingly calls affirmative genealogy. Now I want to make clear that it wasn't my goal to be destructively genealogical in writing the book and I differ there with some of my Marxist friends. I think human rights remain really the sole uplifting political idiom that we have left in a very dreary world, after the crisis of many other idioms we preferred first in the West and around the world. Human rights are remainders from the history of idealism, even if we decide that we need to transform it now. And that means that the point of the history of human rights should be in part to emphasize their disturbing features and abject failures so far, so that we can face the future as clearly as possible.

DK: Thank you, Sam. Hans?

HJ: I have a double task now, I think. First, I would like to respond to the questions David posed to us, and then I will briefly comment on the similarities and dissimilarities between the two books, as I see them. So, first, on what David has asked us to answer: "What was the point of entry into your study on the history of human rights?" I said in the preface to my book - quite clearly, I think - that the idea emerged from two earlier books, namely one that is called The Genesis of Values where I've developed - whether it is convincing or not I have to leave it to my readers - a kind of theory that is intended to explain how we develop our value commitments, in what experiential contexts we experience something as self-evidently good or evil. And in another book, which is called in its English translation War and Modernity, I explain the experience of violence, the longterm consequences of the experience of violence, and the problems of the articulation and interpretation of the experience of violence. ${ }^{6}$ At a certain point, I had

6 Hans Joas, The Genesis of Values. Chicago: University of Chicago Press 2000; Hans Joas, War and Modernity, trans. Rodney Livingstone. Cambridge: Polity, 2003. 
the idea of bringing these two projects together. If I don't bring them together, the processes of the emergence of value commitments always sound as if they were exclusively based in what I call "enthusiastic experiences," which people consider to be totally positive. So I'm interested in the interplay between such enthusiastic, positive experiences and the experience of violence - be it on the side of the perpetrator or on the side of the victim.

Now I think logically, in a certain sense, that I had two options in this situation: first, one could examine the influence of the experience of violence on people's value commitments - for example, within the context of Fascism and Nazism, how people generalize their experience of violence into a worldview that the only thing that counts is to be strong - struggle for survival, so to speak; second, one could study the history of violence in light of the possibilities that are available to find a way out of the spiraling escalation of violence, to produce some sort of positive experience in the midst of these horrifying experiences of violence. That led to my interest in the interplay between the history of violence in the 19th and 20th centuries and the history of human rights as one such potential way out.

Now I use, as a shorthand formula for my particular description of the history of human rights, the term "sacralization of the person." I say person, and not individual, to avoid a certain misunderstanding. For the sacralization of the individual can easily sound like the self-sacralization of the individual and that is an important topic in contemporary sociology of religion. People say: "The only thing that is sacred to me is 'I,' myself." And that's clearly not what I mean. So I chose the notion of person that also plays an important role in the philosophy of Max Scheler, Emmanuel Mounier, and others. Sacralization and sacredness: I use these terms in a value-neutral sense, as scholars such as Émile Durkheim, Marcel Mauss, Nathan Söderblom and Rudolf Otto have done since 1900. I emphasize this point because there is a constant suspicion that talking about sacredness means somehow smuggling into the picture some religion, some religious faith. That's not what I mean. That's at least a totally different question. How religious one has to be, that for me is a totally different discourse. What I mean here is maybe we just bracket the term "sacredness" for a moment -, but what I'm aiming at is the history of human rights not as a legal history mostly, nor as a history of ideas mostly, although of course it is also a history of ideas and a legal history, but as a history of profound cultural transformation. I say a profound cultural transformation in three dimensions: in regard to values, and that of course also implies intellectual discourse: what is good, what can be defended as good, and so on; in regard to practices, when practices may change without much intellectual discourse, people just become more sensitive to something, they are more easily motivated by something than they are in another phase of history; and of 
course in regards to institutions, and among institutions, legal institutions are perhaps the most important ones.

But my whole approach is "experientialist," not "culturalist," and I put an enormous emphasis on the dynamics of experience, and on the dynamics of the articulation of experience. For me, this notion of sacredness and sacralization is very handy because I am interested in experiences that have two features, to use a more analytic language. They must be affectively intense. It's not just "I have an opinion, ok?” and you say "No, I have a different opinion.” They are affectively intense. There is an element - on the phenomenological level of the experience - of what I call "subjective self-evidence.” That means: I personally have the feeling that I have recognized something as good or evil and I personally don't have the feeling that I need any argumentation to prove that that feeling is justified. I emphasize personally because I'm not irrational to say: "We don't need argumentation. It's just a gut feeling or something like that.” No, I want to do justice to the empirical fact - and I think it is an empirical fact - that even in processes of argumentation we are mostly guided by pre-theoretical, pre-argumentative experiences of self-evidence, and that we have to grasp this element of the phenomenology of the emergence of value commitments. Now I did that in the book very selectively only in regard to four historical cases: the emergence of the main declarations of the late eighteenth century and the emergence of the 1948 Declaration as two specific events; and as two drawn-out processes the abolition of torture in Europe during the 18th century and the abolition of slavery mostly in the United States during the 19th century.

Here, a first brief response to David's questions: I see my own book as being totally selective - thus, not as an exhaustive study of the history of human rights. When I end in the year 1948, I do not make the claim that the history of human rights should end in that year. And I do not study the consequences of these codifications, as you have said - and you are right, I fully agree with you -, but somebody should study the consequences of the codification. So I have nothing against that, but one can ask the question: "How did that codification come up?" I mean that this is part of a larger question. Another element I should emphasize here is: it is selective even in the sense that I do not say these four narratives or these four stories form one grand narrative of the history of the sacralization of the person. No, these are four stories. There is no master process of sacralization of the person. There are other processes, other sacralizations, of the nation, etc.

Now on David's second question: I think it was relatively easy for me to do research on and write the first three chapters and the last one on the drafting of the 1948 Declaration. These are the sociohistorical chapters. Chapters Four and Five were much more difficult. And I think it makes sense to highlight these two chapters very briefly. The most misunderstood one is Chapter Five. I deny in the 
first three chapters that we can derive human rights from Christian roots. But I'm also writing as a Christian, so in the historical-sociological parts, I would say, I have to ask myself the question: "Is there any evidence for the Christian roots?" My answer to that is: "There is no such root." So I go on to say: when an interesting cultural innovation like the idea of the sacredness of the person comes up, all religious traditions, all secular-intellectual or political traditions, including the Christian one, somehow have to define their relationship to this cultural innovation. Hence, I try to describe that at a certain point those Christians who did not position themselves in opposition to human rights started to look for elements in the Christian tradition, elements that allowed them to say: "This is what we have always already wanted to say, but we were just not able to articulate it well enough." And what they discovered are the two elements of the Christian, and partly also of the Jewish, tradition: first, human beings are created in the image of God; and second, we are the children of God. These are the two basic elements.

Now I know that some people - I know that from reviews - read Chapter Five as a place where I am being totally self-contradictory. They believe that in the first three chapters I deny any Christian roots and in Chapter Five I somehow smuggle the Christian roots back in. No! I'm just being honest. As a Christian and as a historical sociologist, I say what I think about the history of human rights. That is, from the perspective of historical sociology and from my Christian convictions. And if I were a Muslim author, I would say that somebody would have to write Chapter Five in such a way that this idea related to the Muslim tradition. And if you are a secularist, you have to do exactly the same and explain how this idea is connected to your utilitarianism, Kantianism, existentialism or whatever your philosophical conviction is.

Now this is getting too long, so maybe I don't say anything about Chapter Four in which the idea of "affirmative genealogy" appears. But let me make one short remark. I called it neither Kant nor Nietzsche, and a very benevolent person told me: "You should have said Kant plus Nietzsche." For what happened was I alienated all the Kantians and all the Nietzscheans simultaneously. But if I had said "Kant plus Nietzsche," both the Kantians and Nietzscheans would have loved me. So that was clearly a mistake.

Now let me turn to the discussion with Sam. I agree with Sam that there are many similarities. I would emphasize as the main similarity that we both emphasize contingencies, that we are both skeptical of teleological historiography. I would like to take issue with your usage of the term "church history," though. I think this is unfair to contemporary church historians. They are very serious scholars. They do not write the history of the church in a simplistic, hagiographical sense, as you seem to assume. But I also agree with you that in a certain sense there is no controversy. We have written two books about two different topics. 
Now the controversy possibly arises because you do not simply make the claim that you are writing a book about the history of human rights after 1970, but you emphasize very strongly the discontinuity in the history of human rights.

Instead of arguing about all sorts of historical detail, I would like to make a more constructive proposal and maybe you can respond to it at some point. I personally think that there are three breakthroughs in the global history of human rights and one can clearly distinguish the three from each other. But a complete history, so to speak, has to do justice to all three of them. So the first I would say is - in my language - the emergence of moral universalism in the Axial Age. There is a point in history when religious and philosophical ideas came up, that what defines the good is not what is good for us in the sense of a somehow limited community - tribe, state, family, religious community -, but for all human beings, maybe even including all future human beings. I follow Karl Jaspers and a few of you might know that I've just published a book in the US with Robert Bellah on the Axial Age. ${ }^{7}$ This is more global than just speaking about Greek philosophy and Hebrew prophets, for example, although they clearly belong to that story. So, from the Axial Age onward, from 600 before Christ and onward, we have in different civilizations, religions, and philosophies the articulation of basic ideas of moral universalism. Their emergence is connected to the problems of the archaic state. I don't have the time to explain what I mean, but I have to mention that because I think all these phases are somehow connected to phases of the history of state formation.

The second breakthrough is connected to the history of the early modern and absolutist state and leads from the moral philosophies and religious articulations of universalism to state-based codifications and that happened in the 18th century. You are totally right to say, of course, when you emphasize in your book that it's always on the level of the state: Yes! But it was an attempt to codify and to institutionalize certain ideas that had been around since the Axial Age. And what happened after the Second World War in the 1948 Declaration, but with much more force later is an institutionalization that is not restricted to the nation-state, but the attempt to develop international mechanisms that oblige the individual states. That was a reaction, first, to the totalitarian state and, then, to the colonial state. So in that sense what I have done in this particular book is mostly about phase two, and what you have done in your book is mostly about phase three. And I think that I have done in other publications, and will do in other publications, something on phase one. The real history would have to bring

7 Robert N. Bellah and Hans Joas, eds. The Axial Age and Its Consequences. Cambridge: Belknap Press, 2012. 
the three things together. How do actors in the second phase relate to the ideas of the first phase? Do they see themselves in continuity with the axial religious innovations or do they position themselves against - but in the sense of we are more axial than - the axial innovations. And the same is true for the third phase: how exactly do we describe the institutionalizations in-between? What is the relevance of natural law doctrines for medieval law and so on? But there could be an integration of the different perspectives and you have been very polemically attacked because of your exclusive emphasis on the third phase. Now in my picture I have been similarly polemically attacked because of my main emphasis on the second phase. People say: it's just ridiculous to deny that there were ideas of universalism around Plato or Jesus Christ, as if I had ever had any motivation to deny that. Okay, I think I will leave it there.

DK: Thank you so much for the wonderful outlining of your arguments and for the resonances and disagreements. Sam, would you like to respond to Hans's remarks?

SM: I would like to respond to Hans’s opening statement.

DK: Yes, please go ahead.

SM: Most of what you say sounds sensible to me. I'll just make two broad points sticking again with where I disagree against the background of general agreement. One is about the background of the experience of violence, which is emphasized in a chapter of Hans's book.

In contrast to Hans, I think that appealing to violence as a predicate for values is an incredibly weak explanation of them - on the grounds that it seems to be behind a huge profusion of possible value commitments. To make this point, we can stop the clock in the 1940s and ask: "What was the normative response to World War II and the violence that it unleashed?” After all, most people found both horrendous, although they were not yet concerned with the Holocaust in particular. If you'd like to take this point about the Holocaust up, I'd be happy to do so. One response was realism about power politics. The United Nations was not founded on principles of justice, but the states came together, with the Allies leading them, and founded what was a great power organization. Some, at the time, felt it was a reversion to the Concert of Europe after Napoleon. It's true that human rights were mentioned in the UN Charter, but the declared goal of the organization to this day is peace rather than justice. So that was one response to the violence. And it's only in our day that the charter is being reread to incorporate concerns for justice and episodes like the invention of the responsibility to protect. 
More broadly, I think the main normative response to World War II was the huge ascendancy of nationalism, which, indeed, the postwar peace ended up promoting as the globally normative political form that it had never been before. If we take the European continent even in the east where many Jews lived, anti-fascism was an exceptionally powerful response ideologically to World War II, and maybe the most directly internationalist response to the Holocaust at least for a few years. Just on the basis of these examples, it seems as if, whether at that moment or frankly at any point in history, violence underdetermines any possible value response; it doesn't necessitate a commitment to human rights, let alone international human rights.

I broadly agree, in part for that reason, with Hans's notion of a human rights history that has many phases and integrates continuity and discontinuity. I didn't have a chance to respond to David's initial questions, but I was reacting polemically to a historiography that emphasized the age-old continuous evolution of human rights and I wanted to show that a powerful case could be made to the contrary, but in the end I take it as obvious that, for example, when we come to the idea of a formal individual right or the content of some human rights we have today, we are dealing with very old items in the Western repertory. Nothing in our time would have happened without the Universal Declaration of Human Rights, even if it was re-appropriated later in very unexpected ways. I think my point was primarily that the continuities that are there are obvious and boring and the discontinuities are interesting and compelling.

I think I would disagree about some of the specifics of Hans's presentation of the stages that he lays out. It's very controversial, for example, to claim that before the Axial Age there were just parochial moral cultures mired in tribe and family. Students of the human-animal border, just to take a very interesting case, insist that the implicit idea of humanity as a species-concept must be far older than the Axial Age. More importantly, the idea of the formal unity of the human type, like the moral significance of membership, seems to be a gateway to a huge profusion and controversy amongst various universalisms that would follow. It's a gateway to Christianity and all the other universalistic religions. Indeed, I understand history as late as the Cold War as a contest of moral universalisms. It's not as if moral universalism, like violence I discussed before, does anything more than establish a massive, open field for the contestation of different visions. Accordingly, my own argument is that many of these had to collapse in their appeal before human rights became the straightforward or intuitive form of cosmopolitanism.

When we come to the early-modern state, I would go a bit further than saying that the formulation of universalistic rights norms occurred because of various reasons at the state level. Rather, my deeper point, at least as I understood it, is 
that rights are connected to the erection of sovereignty, including borders. What were the Americans and Frenchmen trying to do when they announced human rights in 1776 and 1789? They were trying to gain sovereignty - to erect it on the ruins of empire and absolute monarchy through the tools of violence - and that just seems utterly different than what human rights mean today. Now they're about the qualification of sovereignty or the subjection of sovereignty or subordination to global legal and other technologies.

1948, I think, is clearly an important moment. Yet I myself would want to tell, as I indicated in my opening remarks, a more melancholy story, in which in 1948 the world had a brief moment of consensus around national welfarism. The colonial world wanted it, too, and that was why decolonization happened. Our time, in stark contrast, is the time of the collapse of national welfarism and it seems to me that international human rights could be more a symptom of this loss, rather than a grand breakthrough. But I recognize this is a very controversial argument to make.

DK: If I may interject for a brief moment - and I will let you respond to Sam's note in a brief moment. I would like to ask you to consider the following, as you respond to Sam's note, and that is: I would like you to theorize - and I think cultural studies scholars would be very interested in that - how you envision the process of sacralization and then that of utopianization. I think that might help us look beyond the disagreements. Because in your book, you say that you take much more seriously into consideration the concept of inclusion in a Foucauldian sense to think about, let's say, the process of cultural transformation, such that it's almost like a Hegelian Aufhebung, where you do take some vital concepts of the Axial Age, but you don't take them as such; instead, you transform them - you leave off some parts and you include new meanings - and they undergo some kind of universalization in very affective ways, in very experiential ways. If that is true - if that describes on a theoretical level the process of sacralization - I would like Sam to tell us: at what point do you say utopianism has happened? What describes the past utopia? What describes the present utopia? How do those transitions happen?

HJ: First, just as a clarification. I did not say that the experience of violence leads to a commitment to universalist values. On the contrary, I said that normally it leads to revenge or to the formation of a worldview in which revenge is justified, or maybe to power political realism, but retrospectively we can select those historical cases in which this did not happen, but people derived from an experience of violence the conviction that there must be a way out, as I have said before, of the spiraling escalation of violence. And then it is justified, I would say, in an affirm- 
ative genealogy to study those cases and it's not an objection to this study to say: These are rare cases - yes! That is exactly the reason why I'm interested in them! Not because I think they are representative in any quantitative sense. Nazism you know what I am saying, but you didn't do full justice to the following distinction in your book - the importance of Nazism for the discussions of 1945 and the importance of the Holocaust. And I agree with you that the Holocaust was not crucial, but I think people like Johannes Morsink and others have convincingly shown that Nazism in the sense of some tyranny that is aggressive, enslaves other peoples and so on, was crucial for the debates. So it's remarkable that the relative neglect of the Holocaust was not just a phenomenon of this committee. It was a much wider phenomenon. Third, I agree with you - and that was Karl Jaspers's point when he developed his idea of the Axial Age or when he invented the term - that we live with a plurality of universalisms, that all the attempts of, let's say, Christians or Enlightenment rationalists who say "I am the universalist, the others are not universalists" are wrong. There are Buddhist universalists. This, again, does not mean everyone is a universalist. What I'm saying is: what we need politically is a coalition of all universalists, be they Christian, Buddhist, Jewish, secular, this or that. Against all non-universalists, be they Christian, Buddhist, as in Myanmar, or secular. So we live with a plurality of universalisms.

Now I disagree with what you say about collapse. If you include in your argument for a moment Christian proponents of human rights, then you will see that they have not become proponents of human rights because they think that their Christian faith has collapsed. So what you are saying may be true for a certain generation - I would say, mostly of former leftists - but it's certainly not generalizable. And even the choice of the word "utopia" for me is totally unconvincing. For me, at least, human rights is not a utopia. I want to live in a society where there is no torture. But that is a kind of minimal standard. I would never say that I live in a utopian society because there is no torture here. It can be a society with extreme social inequality and ecological problems and everything is very far from utopia. I think these two things are connected, to be honest. You somehow argue in a way that is very far from what has been, for example, the Christian worldview for a very long time. That is, there will never be a utopia on earth. That human beings will remain tempted to do evil things for all imaginable futures and that we need the law to prevent them from doing that. But that we need not only the law, but also value-related education, for example, religious education for that purpose. And if I'm right in regard to that, I think this main narrative that led to the title of the book, that this is somehow a utopia, and somehow the most important thing for this is this exhaustion of earlier utopian imaginations, I would not deny that it is true for certain groups, so to speak, and some people. But I think you're overgeneralizing. 
SM: I want to concede that the notion of utopia in my title of the book is woefully undertheorized. I had something very simple in mind: I wanted to have a good title. But I mainly had in mind the pedagogical experience from which this book arose, which is, confronting young students today, who come to university and want to save the world, or at least make it better. I think making it better has some utopian features; you don't have to want to save, transform, and utterly perfect it to be a utopian. And I asked myself why it was that, in their generation, human rights were the sole version of idealism and activism in which they would engage. This fact marks out their generation from all those that preceded it in history. I wondered: "What were the historical circumstances in which this transformation could have come about?" I often talk to my students about the 1960s and 1968 at Columbia University where I have taught and I show them pictures of what happened. And no one said the words human rights as part of student activism. Though they certainly wanted a better world, they thought about it and mobilized in its favor in profoundly different ways.

I do, however, want to concede Hans's point about Christianity. I think the vast majority of proponents of human rights in the 40s - not that there were many - were Christians in transatlantic affairs. To me, actually Christianity, especially on the European continent, has gone through a world-historical collapse. It might not have reached Hans, but the transformation and decline of Christianity is a remarkable event in world history, and, to me, is actually very germane to understanding the centrality of human rights, though it is only one feature of this centrality. Now, it is not obvious whether this secularization of human rights involved the rise of a truly non-partisan set of beliefs that's compatible with Christianity, or a mere version of Christianity that has survived the collapse of churchgoing. But I wouldn't want at all to exclude Christians from the story of the collapse of prior belief systems, although I do agree my model is best applicable to the secular left.

HJ: Did you really just call the Vatican II a collapse? I mean, you can complain ...

SM: Vatican II paradoxically set the stage for the collapse of West European Christianity in both its old and its renovated forms.

HJ: ... that it didn't have enough consequences, but at the time it was a revitalization ...

SM: Of course. It was.

HJ: ... rejuvenation - not experienced as collapse. 
SM: True, but that was a long time ago.

HJ: Yes, okay, but then we have to become more specific, I would say.

SM: Right, this is a detailed topic.

HJ: Yes, yes. I'll leave it aside.

Another potentially controversial thing in the book, and also in your own summary here, I do not agree with your relatively dismissive way of speaking about national self-determination both in regard to liberal nationalism in the 19th century, and in regard to the anticolonial movement. I mean, for me, it is easy to imagine that somebody says, even if my highest goal is human rights, what we need first is national self-determination. I fully agree that not all the people who were in favor of national self-determination were ever really in favor of human rights, so to speak, but that national self-determination can be a presupposition for human rights. I personally think you do not take that seriously enough in your book.

Now to your question: you know, when I'm speaking about sacralizations, whether in the past or today, I do not say sacralization of the person is the only one. The idea comes from Émile Durkheim - I think Durkheim sacralized two things simultaneously: the French nation and the human person. If you do that - sacralize two things simultaneously while being intellectually consistent -, then you have to say: "How do they relate to each other?" And I think his way of relating these two things to each other was to say, France is the nation of human rights. To be a French patriot or even nationalist means to do something for the sake of human rights. But that is not necessarily the case and people live with enormous tensions. And I had in Die Zeit - I think one or two weeks ago - I had an article that was based on a dinner conversation I had in Charlottesville, Virginia, where the host asked me: "Do you think that human rights are now stabilized?" And I said: “No, I don't think so. For example, I see a constant tension between the demands of, let's say, national security and human rights - sacredness of the person." And only because he really exerted some pressure, I mentioned Guantanamo. Then, he said: "In Guantanamo we defend the human rights of our American citizens.” And if he hadn't been my host, I would have said, this shows that you have never understood the basic idea of human rights. But if we take this person as in any sense representative, it is deeply depressing. It means that some people, in a serious tension between two values that they both take very seriously, may decide in favor of the other one and say: "Under these circumstances torture is justified." I imagine the same to happen in Germany - I should add - if we experienced a similar attack like on 9/11. So I'm not saying this is American, that here everything is much more stabilized. It's a different experiential 
background in that sense, at the moment. But this makes me rather pessimistic. So at the same time, of course, sensitizing effects of these processes that led to the institutionalization of human rights may go on to change the mentality in regard to gay marriage, but at the same time, people may, in a trade-off, reduce their support for human rights. So in that sense, I'm not really optimistic for the future.

DK: Questions please.

Audience: The example you gave about Guantanamo illustrated perfectly what I think Sam Moyn wants us to consider, namely the distinction between citizenship rights and human rights. In a way what you're pursuing is an idealist account of the development of rights that goes through the various stages, but until today we are still stuck to the notion of citizenship rights, which are based in nation-state rights. And human rights to this day are not enforceable - universal human rights on a global scale - and that is a rather recent development. There's an argument that under the International Criminal Court and so forth, there are attempts to institutionalize them. And so far, we do not have a legal framework to enforce human rights. So I think that maybe we could try to work with this distinction between citizenship rights and human rights. I mean when the French invented human rights for themselves, at the same time they had the code noir in the colonies. That is true for all the European colonial powers that their notion of citizenship rights was always based on exclusivity. And, of course, it didn't include women - it didn't include other non-Christians, etc. So I think we should really try to be a bit more careful with our terminology when we talk about what kind of rights we're really addressing here because the universalism of earlier times was not the universalism that exists today.

HJ: I agree with everything you say and realize that you think it somehow contradicts what I said before and that is a mystery.

Audience: No, no. I thought your example illustrates perfectly that tension between...

HJ: Yes, there is this tension!

Audience: ... between Americans trying to protect their citizenship rights and the notion of human rights.

HJ: I see, let's say, an ambiguity in the notion of citizenship rights. You could say: "We declare that all men are created equal. But of course, here, when we codify 
that, we can only do so in the framework of our own state.” But if you declare: "These are the rights of Englishmen," then you do not even assume that they should be institutionalized in the other states as well - it's just the English tradition then. So in that sense, I see a difference between England and the United States in the late 18th century and you could apply this distinction to all cases. And what I would say to this guy in Charlottesville is, of course, that he, let's say, reparticularizes the American understanding even of citizenship rights. So it's not citizen rights versus human rights. One distinction is codification on the national level and implementation mechanisms versus codification on the supranational and international level - that's one distinction. It's not the same distinction as the distinction between citizenship rights and human rights.

SM: I think you've made the point that the distinction helps us get historiographically at the novelty of supranational human rights politics. I think Hans is confused when he says I'm dismissive of national self-determination. In fact, I want to rehabilitate nationalism and the experience of citizenship politics - to reclaim them from the relative decline in prestige which both have suffered. I actually trace that loss to decolonization. In my understanding, Adolf Hitler didn't convince the world to give up on nationalism. Indeed, it seems as if at the time of the Universal Declaration rights were reaffirmed as having their basis first of all in a properly governed national welfare state. It was really later, with decolonization, when nationalism as the primary conduit and device of the propagation of rights globally came into disrepute. And I think this fact is very telling, because it suggests that only when people we Westerners once ruled got national sovereignty or rather claimed it for themselves, sometimes through violence, sovereignty suddenly became problematic. And we developed new devices that were no longer formal, imperialist devices to police their conduct. And that's, I think, a pretty big part of the history of human rights, especially of post-Cold War human rights.

But framing things my way also helps us see that whatever salience human rights have achieved, it's not because they've definitely changed real outcomes for humanity. No one would ever ask whether nationalism made a difference, or whether the experience of citizenship made a difference in world history. And yet, a mere ten years ago, Oona Hathaway could write an article called "Do Human Rights Treaties Make a Difference?” Recently, a new book has come out by Beth Simmons that proves that they have helped at the margins. ${ }^{8}$ But the amazing

8 Oona A. Hathaway, “Do Human Rights Treaties Make a Difference?” Yale Law Journal 111, no. 8 (June 2002): 1935-2042; Beth A. Simmons, Mobilizing for Human Rights: International Law in Domestic Politics (Cambridge: Cambridge University Press, 2010); see also Samuel Moyn, "Do 
fact is that the debate had to take place at all, because we would never deny the emancipatory role of nationhood and the quest for citizenship within nations in world history. By contrast, human rights politics seem to be a very narrow form of mobilization. The Americans didn't name and shame George III only. The Frenchmen didn't name and shame their king; they claimed their citizenship through a refounding of sovereignty. Human rights politics, as we know them, seem to be much less effectual. Indeed, that is my main complaint, and my reason for historicizing them in a more negative, or, let's say, deconstructive way, even if I don't mean to be destructive. Because my complaint about international human rights is that they don't seem to have found any politically effective form that gives them the emancipatory force that national self-determination at least for awhile had in spite of all the terrible things that nations have also done - to their own people and other people.

Audience: Maybe, well, I'm not sure, but it sounds very much like the point is where the mechanism of reverting human rights on those who claim them for themselves - that's the point where the systematic difference may be. Or at least it is an important point for making human rights internationally or universally valid. I mean, if the United States says, for example, we are furthering human rights all over the world, but they maintain Guantanamo for safeguarding their people from terrorist attacks. So the reciprocity, which forms part of a universalist construction of the human rights thought, is not given. The United States attacks Nicaragua. The International Court has a judgment on the United States and says, well, they are guilty of crime against humanity and, then, there is no reaction. Why? Because there is no enforcement, and there is no will to put forth human rights as human rights, which are really human rights, and have this logic of reciprocity.

SM: I do agree that you are getting to a pretty fundamental difference between our approaches, which I think should be out there, just so that people can decide whether they're compatible or incompatible. Both Hans and I think we need to take the norms of human rights and connect them to something else, for the sake of understanding their genesis and why they were directed in some ways against some countries and not others and so forth.

Human Rights Treaties Make Enough of a Difference?” in Conor Gearty and Costas Douzinas, eds., Cambridge Companion to Human Rights Law (Cambridge: Cambridge University Press, 2012). 
Hans gives us a sociological context, drawing on classics and social theory and ransacking them for any insight the history of social theory as we know it - Durkheim, Weber, and so forth - might have to bring to bear on the history of these norms. And then he stops the clock in 1948. But to me, what truly matters is what happens to these norms in our time, which is, by the way, what also has to explain our own contemporary scholarly interest. It may be true that in the historiography of human rights we can cite Georg Jellinek (1895), as Hans does, but recall that Jellinek's book concerns one declaration; and as far as I know, it the sole book ever to think about the French Revolution in terms of human rights until our time. ${ }^{9}$ The truth is that there was no human rights historiography until ten years ago. And so, to me, it's not the sociological context that's motivating us as scholars to think about where they came from, but really the postwar, including the great power context. So I think that's a pretty big difference.

HJ: This is really empirically wrong, if I may say that. No, I mean simply on this level of Jellinek's book, there was a huge international controversy. I have several files at home with hundreds of pages of contributions. And it's not true that there has been a historiography only in the past ten years. I mean there were books at least in German republishing important papers from this 1900 controversy in the 1950s or 60s. I could give you a whole bibliography. Émile Durkheim wouldn't have been able to develop what he said if it hadn't been for a certain context. There was a lively debate about the history of human rights around 1900. And that does not fit into your picture, but you cannot deny that it was there.

SM: That's a fair point.

Audience: I do not see so much difference between the two approaches, because if the sacralization of the person is a sacralization of every person, accepted by every person, and reverted on every person, so what's the differences? How this idea is applied, and who applies it, and the power structures, which are behind plight and which are behind the legal systems we have and the political contradiction - you know, the story.

9 Georg Jellinek, Die Erklärung der Menschen- und Bürgerrechte: ein Beitrag zur modernen Verfassungsgeschichte (Leipzig: Duncker und Humblot, 1895). The contemporary classic on human rights in the French Revolution is Lynn Hunt, Inventing Human Rights: A History (New York: W.W. Norton, 2007). 
HJ: Sam has - now you could say - a more precise or narrower understanding of human rights with the emphasis on international institutions and international social movements. I could grant that because my main concept is the sacralization of the person and that does not necessarily take on a legal form. I tried to describe why people - let's say, around 1700 - didn't find torture a good thing, but nor were they terribly motivated to abolish it, and why this changed in the course of the 18th century. And for that argument, it is in a certain sense completely irrelevant whether they use the word "human right" or not. I would include that in such a history irrespective of the vocabulary the actors used. But, of course, if you defend a very narrow understanding, then it becomes important whether they said that, whether they articulate their ideas in those terms. If not, it does not belong to the narrative. Both things are justified. I mean, you can write a conceptual history of the notion of human rights. Then this is totally justified. But if you think in terms of a cultural transformation in which every person is respected as a person, then it doesn't make sense to restrict yourself to this literal meaning. So, in that sense, it's not controversial again!

SM: What you say makes a lot of sense. I just want to be clear that, no matter what importance one grants to post-1948 developments, one would of course need not simply an intellectual history but an experiential genealogy - affirmative or not of things like the French Declaration of the Rights of Man and Citizen and the Universal Declaration. Where the controversy comes in is what importance that has for explaining global human rights politics today. On the narrow issue, torture was not abolished in the 18th century. It was a familiar part of imperial rule until the 1950s, 60s, and 70s, when the...

HJ: The empire ...

SM: That is to say, the whole world.

HJ: Yes, yes - I agree!

SM: And finally Amnesty International had its campaign against torture in the early 1970s. This was a transformative event for global norm-setting - although, of course, as we know, when it comes to my country, and many of its partners in the war on terror, the practice is still not gone. So the "consensus" we're speaking about has to be detailed, and often it's at a purely normative level. And with regards to the larger picture, it seems to me that the sacralization story works for a few places early in history, but not for the globe after 1945, when one needs some other account. And so the compatibility would have to be sought on that basis I think. 
DK: And I think I have a perfect quote here. This is a quote from Sam's book. I would think that it speaks directly to Hans's book right now. He writes: "As time passed after World War II" - and this is Sam once again - "such personalism more and more simply rephrased anti-communism and Western unity, rather than offering a philosophy of global amity. There was no serious promotion by European international lawyers of human rights as a wider project, as the European convention signaled values without bringing a serious legal regime into being." And so this is the point where Sam thinks about the importance of social movement and its impact on international lawyers.

Here comes my question that follows up. Hans on the other says that by affirmative genealogy of human rights, he means a certain work of translation, shifting - and he also calls it generalization of values, experiences, subjective evidence, after Jürgen Habermas and Talcott Parsons. And I think this is toward the end of your book where you make a few observations in regards to what happens much more in contemporary times. So, the first question for Sam is: Do you think that Hans's model - that is, sacralization of personhood - explains what happens with international lawyers beginning 1977? If not, why not? And the analog of that question for Hans would be: what shape does that social movement take, as it undergoes a certain universalization of values for the dignity of the individual being? So that we get a more concrete sense of the political actors who are operative in that universalization. Perhaps that's another way of fine-tuning some of the historical differences, as you pursue your different disciplinary approaches to the history of human rights.

SM: As I've indicated already, I don't think the sacralization of the person is a very useful concept for explaining the details of history after 1945 - whatever its use is before. I'm officially going to be neutral about whether Hans successfully explains the ancient prehistory of post-1945 human rights politics. All I want to commit to saying right now is that I can't see the value of the concept for explaining what happens since.

What happens since, it seems to me, has to do in part with some of the topics Hans takes up in his last chapter. But I would cast the "generalization of values" in a different way. I don't think the UDHR should be seen, as he does, as coming about thanks to moment of multicultural communion, mainly because almost nobody from around the world was in the room - and those who were there were diplomats trained in Western universities as, by the way, many diplomats to this day are. We shouldn't think of the UDHR as a popular or grassroots product. It's a product of diplomatic elites that only later found the backing of social movements even in the North Atlantic under very different circumstances. It's actually very hard to say even today whether human rights have found a global backing at all. 
On a new part of the website Open Democracy called “Open Human Rights," some political scientists have recently tried to investigate empirically, rather than just believe in, the global salience of human rights ideas. ${ }^{10}$ And they've concluded that to date it remains an exceptionally elite set of norms in the global South. This finding, of course, doesn't mean that human rights don't have a grand future ahead of them.

In my view, however, it was for good reason that after 1945 nationalism remained prestigious and emancipatory for a long time - the Jews wanted it in Israel, all of the many peoples under empire wanted it and pursued national self-determination for the sake of individual protection, but also as a project of collective emancipation. When the 1970s dawned, the most significant challenge to the Western hegemony that had led to empire was the New International Economic Order (NIEO) proposals, which offered a plan to redo the world order - and especially the economic world order. But the NIEO was destroyed. It doesn't seem as if human rights politics, as we know them, are waiting to happen after 1945, until these really surprising events intervene and I don't see the sacred having much to do with it.

HJ: First, just to be clear, because you mentioned torture in European colonies, I fully agree with that. But I had said the abolition of torture in Europe.

\section{SM: Precisely.}

HJ: I did not say on a global scale. And actually, I've even written a new manuscript on exactly that. ${ }^{11}$ I'm interested in destroying this European triumphalism - we abolished torture, when it's not true for the European colonies. This has at least become the European self-understanding. To David: Please, the two terms value generalization and affirmative genealogy have very different meanings. Affirmative genealogy refers to this question of how do we, in view of our ideals, reconstruct history in a non-teleological way, so that those ideals are not this necessary result of the historical processes, but nevertheless we defend them as our ideals, see them in all their contingency, but defend them. This is about the role of historical reconstruction in such a quasi-normative argumentation,

10 James Ron et al., "The Struggle for a Truly Global Human Rights Movement," Open Democracy, http://www.opendemocracy.net/openglobalrights/james-ron-david-crow-shannongolden/struggle-for-truly-grassroots-human-rights-move.

11 Hans Joas, Slavery and Torture in a Global Perspective: Human Rights and the Western Tradition. Leiden: Brill, 2014. 
whereas value generalization refers in Parsons to a dialogue between the representatives of different value systems and how they discover surprisingly, so to speak, that they share more, how they reinterpret themselves, re-articulate their convictions, in a way that... - okay, I would need more time to illustrate that.

Now your question about social change after 1945 or 1948 and whether this notion makes sense. I would say, it makes more sense the more you think of unintentional processes of cultural change. Let's say, in Germany, the relations between medical doctors and their patients changed in the direction of more respect for the autonomy of the decision of the patient about his or her own body. This is not mostly - certainly not at first - a change in law. And maybe not even so much a consequence of intellectual discussions about that. It's a kind of gradual, almost unnoticed change. Or, at least, there are such cases. I mean, if you show me that this is not the case; that there was an intense debate - I missed it - that may be. But I think that nobody can deny that there are such changes, with regard to parental attitudes to their children, to sexual rapprochement or such processes. I think we need some term for such, let's say, intuitive change of cultural attitudes. So that's part one.

And the other thing is, of course, your question aimed at social movements. There I would like to, if I may, refer to my chapter on the abolitionist movement, where I mention three elements for the explanation: one again is sacralization, but only one. And sacralization in the sense of, let's say, some Christians discovered that their Christian conviction should always have meant: abolish slavery. But it didn't and other Christians didn't share this. But for them, this was a kind of revelation. William Lloyd Garrison: I don't want to live one more day under the conditions of slavery. I have recognized what the absolute evil is: slavery. And so I will do everything to abolish it. I think for this process such quasi-religious terms like sacredness, revelation and so on really make sense. Now, I say in the book, this has to be connected to processes of a much more rational kind - for example, of the cognitive attribution of responsibility: what can I do about it? This is not sacralization, of course, and I don't call it sacralization. But that is the empirical study of facts, for example, and how am I connected to these facts.

I've recently used the following example, I'm deeply convinced that there are terrible labor camps in North Korea, but I have no idea what I can do about them. If you show me that my shoes have been produced in a North Korean labor camp, things change for me; they change cognitively. I've been against these labor camps before, but I had no idea what to do. And that may mean that now I have some idea what to do. And there come in organizational questions, like the role of transnational advocacy networks. So for a model of a social movement you need much more than this notion of sacralization, but sacralization remains an important part. Because you won't have an intense movement that moves people, 
so to speak, without such revelations and such important emotional foundations or whatever.

Audience: I think there is one important point in talking about the social movements - it is the dialectics of resistance, which took place during the 1990s. There was a big debate, you surely remember, about the validity of the human rights question in Asian cultures and among indigenous peoples. In Latin America, for example, in the beginning of the 90s, members of indigenous peoples in resistance would not accept human rights, the human rights discourse. But then, during their resistance, they took up more and more human rights laws and brought them into their own strategies. Consequently, the concept of the person is important here because they did not take up the European, individualist formulations, but they took up the sense of personhood and the way they culturally understood personhood. Now, the debate is going on about the rights of tribes.

HJ: The European tradition is also much more pluralist. It's not just liberal individualism. And Sam has written a very good article on personalism. Also, I would say, this in itself is pluralist. And I use the term person. But that does not mean that I share all of the convictions of earlier authors for whom the concept of person was crucial. But all this is totally complex, of course.

I would just like to conclude by saying, of course, yes, we disagree in our descriptions of the drafting process of this 1948 Declaration. Of course, I mean, empirically, you are right. This was a diplomatic elite, but what else was to be expected? I'm against saying, since this man from Lebanon was Christian, or since the Chinese had already spent time in the Western world, they are not authentic representatives - that I wouldn't buy. Because I think this is a kind of essentializing now of the non-European in the sense of: we only take those people from Asia seriously who have never been in a Western country, never come into contact with Western thinking. No. It was an elite phenomenon. But it was a productive process of communication between people with very different religious and philosophical backgrounds. Of course only very, very limited. Again, I'm not saying that whenever these people come together, something positive comes out of that. But in rare cases - and we should look at these rare cases - something positive comes out of that. And I think that 1948 was such a case. It was positive.

SM: Just very briefly in conclusion, I just want to say to the audience that, of all the things I loved about Hans's book, I think his sketch of a theory of affirmative genealogy is perhaps the most pioneering and provocative, because it is applicable to the sociology of any value formation. Which of course then raises the 
question, which it is applied to. And presumably, we have to know why we're not giving an affirmative genealogy of nationalism anymore, but human rights. And I purport to have tried to address that question.

DK: On that note, we have already extended the discussion for ten minutes. So I think, on that note, it's time to thank our two speakers for their wonderful engagement. Thank you so much for joining us. 